\title{
Using an Escherichia Coli K-12/recA-gfpmut2 Microbial Biosensor to Assess the Impact of Cyclophosphamide and L-ascorbic Acid Residues on Living Bacteria Cells
}

\author{
Marzena Matejczyk*, Renata Świsłocka, Włodzimierz Lewandowski \\ Bialystok University of Technology, Faculty of Civil Engineering and Environmental Engineering, \\ Division of Chemistry, Biology and Biotechnology, Bialystok, Poland
}

Received: 23 April 2019

Accepted: 14 June 2019

\begin{abstract}
Pharmaceutical residues and their transformation products (TPs) have been found in wastewaters and aquatic environments, and they cause adverse effects in aquatic organisms, especially upon chronic exposure and even at very low doses. Cyclophosphamide (CP) is a common alkylating agent that is effective against a wide variety of tumors. L-ascorbic acid is a known water-soluble vitamin that has antioxidant properties. The pharmaceutical residues of both drugs are detected in the environment, and as biologically active molecules they have the ability to affect organisms. In this work we presented the use of a microbiological biosensor E. coli K-12/recA-gfpmut2 in the assessment of the effects of residues of cyclophosphamide and vitamin $\mathrm{C}$ and their mixtures on living cells. In our studies, we have shown that mixtures of $\mathrm{CP}$ and vitamin $\mathrm{C}$ in the highest $\mathrm{CP}$ concentrations are more toxic to $E$. coli strain compared to parent chemicals. In addition, we also found that drug mixtures, especially at the highest $\mathrm{CP}$ concentrations, more strongly stimulate the $\operatorname{rec} A$ promoter and $g f p$ gene expression. We showed that an Escherichia coli K-12/recA-gfpmut2 microbial biosensor is a useful tool in assessing the impact of pharmaceutical residues of cyclophosphamide and L-ascorbic acid and their mixture on living bacteria cells. A stronger impact and toxicity of the mixtures of both tested chemical compounds was found in comparison to parent chemicals.
\end{abstract}

Keywords: pharmaceutical residues, biosensors, toxicity, cyclophosphamide, L-ascorbic acid

*e-mail:m.matejczyk@pb.edu.pl 


\section{Introduction}

Cancer, according to the International Agency for Research on Cancer (IARC), is the second leading cause of death worldwide, with 14.1 million new cancer cases and 8.2 million cancer-related deaths per year. Therefore, there has been a significant increase in the global consumption of anticancer drugs, which are continuously released via excreta into hospital and urban wastewaters, reaching surface waters, soil and sediments. Anticancer drug residues, their metabolites and transformation products (TPs) have been found in wastewaters and the aquatic environment from few $\mathrm{ng} / \mathrm{L}$ to tens of $\mu \mathrm{g} / \mathrm{L}$. Collected data evidenced the genotoxic, carcinogenic, mutagenic and/or teratogenic potential of anticancer drugs that cause adverse effects in aquatic organisms, especially upon chronic exposure and even at very low doses [1].

Cyclophosphamide (CP) is a nitrogen mustard alkylating agent with potent antineoplastic, immunosuppressive and immunomodulatory properties. $\mathrm{CP}$ is used in the treatment of different diseases such as human hematological malignancies and a variety of solid tumors such as breast cancer, carcinoma of the lung, acute leukemia, and ovarian cancer. CP may be also used in the treatment of multiple sclerosis and systemic lupus erythematous [25]. After administration to the human body, CP is primarily metabolized to 4-hydroxycyclophosphamide and 2-dechloroethylcyclophosphamide. The active metabolite 4-hydroxycyclophosphamide is present in equilibrium with aldophosphamide (its tautomer). Most of the aldophosphamide is then oxidized by aldehyde dehydrogenase enzyme to form carboxycyclophosphamide. Only a small proportion of aldophosphamide diffuses freely into cells, where it is decomposed into two metabolites: phosphoramide mustard and acrolein. Despite its vital role in chemotherapy, CP produces some serious adverse effects. CP is known to cause multiple dose-dependent organ toxicity effects. Among these are hepatotoxicity, nephrotoxicity and lung toxicity. Additionally, high therapeutic doses of $\mathrm{CP}$ caused a lethal cardiotoxicity [6-11]. The main molecular mechanism of CP toxicity is due to the production of highly reactive oxygen free radicals by the metabolites phosphoramide and acrolein. Acrolein interferes with the antioxidant system of tissues and produces reactive oxygen species (ROS). Free radicals could prompt peroxidation of lipid in membranes and interfere with cell components, causing disruption of normal functions. Disturbance mediated by oxidative stress results in stimulation of signaling pathways and thus increased production of proinflammatory cytokines and apoptosis [12-21].

$\mathrm{CP}$ is widely used in cancer treatment and its residues were detected in hospital wastewaters from the current limits of detection of up to $15 \mu \mathrm{g} / \mathrm{L}$, wastewater treatment plant influents $(19-27 \mathrm{ng} / \mathrm{L})$ and effluent $(17 \mathrm{ng} / \mathrm{L})$. Hospital wastewaters are usually untreated and discharged directly into the sewerage system, where they eventually arrive at a wastewater treatment facility. $\mathrm{CP}$ has cytotoxic, mutagenic, teratogenic and genotoxic properties, and could have adverse effects on aquatic organisms [1,22].

Clinical studies showed that the use of antioxidants in combination with chemotherapy and irradiation prolong the survival time of patients compared with the expected outcome without antioxidant supplements. Novel methods and alternative approaches have been developed to reduce the side effects of $\mathrm{CP}$ chemotherapy. Thus, the combination of drug delivery together with an antioxidant agent may be a potential therapeutic approach to reverse or arrest the progress of adverse CP effects [23-25].

Vitamin C (ascorbic acid -AA) has often been linked to cancer treatment. It was already in the 1970s reported that high doses of AA intravenously increased the survival time of terminal cancer patients more than four times. It was also shown that AA has a wide variety of effects on cancer cells and the immune system. Ascorbic acid, an antioxidant, has the potential to delay the formation and spread of tumors at all stages. It is known to decrease the dverse effects of chemotherapeutic agents while increasing their destructive effect on cancer cells. Moreover, vitamin $\mathrm{C}$ as an antioxidant and a free radical scavenger serves as an essential cofactor for many enzymatic reactions through iron-, copperand 2-oxoglutarate-dependent dioxygenases. In addition, AA was found to be a cofactor for methyl cytosine dioxygenases that are responsible for DNA demethylation and a possible cofactor for some JmjC domain-containing histone demethylases involved in histone demethylation [24-30]. Laboratory experiments evidenced that L-ascorbic acid has a double-faced nature. Depending on the dose used, vitamin $\mathrm{C}$ has antioxidant properties, or is pro-oxidative. It was shown that ascorbic acid had a genotoxic effect at the concentration of $10 \mu \mathrm{g} / \mathrm{ml}$ and most efficient genotoxic effects at concentrations of 250, 500 and $1000 \mu \mathrm{g} / \mathrm{ml}$. Moreover, it was revealed that vit $\mathrm{C}$ can promote the generation of oxygen radical-induced sister-chromatid exchanges in cultured mammalian cells, as well as some other types of genetic damage [31-33]. Due to extensive use of vitamin $\mathrm{C}$ as a nutrient supplement or antioxidant in a variety of industries, such as medicine, feeds, cosmetic, and food pharmaceuticals, residuals of vitamin $\mathrm{C}$ are present in the environment and affect living organisms. It was registered that vit $\mathrm{C}$ levels in aeration tank and effluent were $7.35 \mathrm{mg} / \mathrm{l}$. The sludge cake in dried beds has been found to be $11.39 \mathrm{mg} / \mathrm{kg}$ and in the sludge cake disposed of for a long time the value is $1.93 \mathrm{mg} / \mathrm{kg}$ [34].

Escherichia coli biosensor strains containing plasmid-borne fusions of SOS-dependent recA promoter-operator region to the green fluorescent gene $(g f p)$ were previously shown to increase their fluorescence in the presence of DNA damage hazards, 
and thus to be useful for genotoxicant detection [31-35]. When a genotoxic mode of action is activated, this leads to an increase in the concentration of fluorescent protein and, as a consequence, fluorescence. Gfp E. coli-based assays employ genetically engineered microorganisms 'tailored' to generate a quantifiable signal that reflects the genotoxic potency of the tested sample. Such bioassays possess several significant advantages, including rapid response times, high reproducibility, facility of use and low operational cost. A lot of laboratory experiments have shown that most microorganisms have similar biochemical pathways as higher organisms. But there are some differences in the scheme of reaction in genotoxicity tests using bacteria and human assays. The priority assay for mutagenic and carcinogenic screening of chemicals is Salmonella Ames assay. The correlation between mutagenicity as measured by the Ames assay and carcinogenicity in mammals was detected. The most important is that bacterial specific metabolism, exceeding a detoxification threshold, or the induction of oxidative damage to which bacteria may be more sensitive than mammalian cells. Moreover, the Ames assay is more expensive in use and it requires high replication, a wide range of controls, extensive culturing and time-consuming enumeration. The Ames test actually measures mutagenicity. The application of E. coli-based reporter genes (e. g., E. coli $\mathrm{K}-12 / \mathrm{rec} A-g f p$ ) assay with activation of SOS repair system following DNA damage allowed us to measure the mutagenic and genotoxic effects of various chemicals and physical treatments in living organisms [32, 36-46].

We know that in wastewaters there are a mixture of drugs. Little is known about the biological effect of that mixture on living organisms. So far, many authors have conducted cytotoxicity analyses of cyclophosphamide in different environmental wastewater and surface waters samples. Little is known about the effects of a mixture of vit $\mathrm{C}$ and $\mathrm{CP}$ on living cells. Hence, in this work we presented the use of a microbiological biosensor E. coli K-12/recA-gfpmut 2 in the assessment of the effects of residues of cyclophosphamide and vitamin $\mathrm{C}$ and their mixtures in the environment. We investigated both chemicals $\mathrm{CP}$ and vit $\mathrm{C}$ in a pure form and their mixtures. In this experimental work, Escherichia coli $\mathrm{K}-12$ contained plasmid transcriptional fusion between a recA promoter that belongs to a DNA-damage genotoxin-inducible group of bacteria promoters, and involved in the SOS regulon response was selected as a testing model for genotoxicity assessment. In this genetic construct we used a fast-folding variant of $g f p$ gene - gfpmut2. Bacterial biosensors detect the genotoxic mode of action of some chemicals and drugs based on fluorescence measurements. This leads to an increased concentration of GFP protein and, as a consequence, its fluorescence. $\operatorname{Rec} A$ promoter-operator, as it was previously shown, is useful for detecting genotoxicants, environmental chemicals and some new antimicrobial and anti-cancer drug candidates [31-34, 40-41].
The cytotoxic potency of tested chemicals were calculated on the basis on the optical density (OD) values of $E$. coli culture. Genotoxic properties were calculated on the basis of the fold increase (FI) of SFI values normalized with control. Antimicrobial activity of chemicals was established on the value of minimal inhibitory concentration (MIC) values.

\section{Experimental}

\section{Chemical Preparation}

L-ascorbic acid and CP were commercially obtained (Sigma Aldrich, UK). Chemicals were dissolved in Milli-Q water and transferred to phosphate buffered saline - PBS buffer (1.44 g Na $\mathrm{HPO}_{4}, 0.24 \mathrm{~g} \mathrm{KH}_{2} \mathrm{PO}_{4}$, $0.2 \mathrm{~g} \mathrm{KCl}, 8 \mathrm{~g} \mathrm{NaCl}$ in $1000 \mathrm{~mL}$ distilled water, $\mathrm{pH}=7$ ) with bacteria strains.

\section{Bacteria Growth Condition}

Escherichia coli K-12 MG1655 and Escherichia coli $\mathrm{K}-12 /$ recA-gfpmut2 strains were cultured overnight in LB agar medium (Merck, Germany) at $30^{\circ} \mathrm{C}$ supplemented with $100 \mu \mathrm{g} / \mathrm{mL}$ of kanamycin (SigmaAldrich, Germany). Colonies were carried to LB broth medium $(10 \mathrm{~g} \mathrm{NaCl}, 10 \mathrm{~g}$ tryptone and $5 \mathrm{~g}$ yeast extract per $1000 \mathrm{~mL}$ of distilled water) with $100 \mu \mathrm{g} / \mathrm{mL}$ of kanamycin and incubated overnight at $30^{\circ} \mathrm{C}$. Bacteria cells were refreshed in LB broth with $100 \mu \mathrm{g} / \mathrm{mL}$ of kanamycin and grown at $30^{\circ} \mathrm{C}$ until the $\mathrm{OD}_{600}$ value reached 0.2. Afterward, the cells were washed with PBS buffer. Growth of bacteria strains treated with chemicals was monitored by the use of standard spectrophotometer analysis (Glomax, Multi Detection System, Promega) of optical density values at a wavelength of $600 \mathrm{~nm}$.

\section{Genotoxicity Testing}

$1 \mathrm{~mL}$ of bacteria cells were suspended in $4 \mathrm{~mL}$ of PBS buffer and the $\mathrm{CP}$ and vit $\mathrm{C}$ were used for genotoxicity testing. The concentration range of the analyzed chemicals was selected experimentally from the minimum level of recA-gfp construct sensitivity and according to the reviewed references recommendation [40-46]. The time of bacteria incubation with chemicals (16 h) was estimated for monitoring the sensitivity of recA-gfp genetic construct. The control sample in PBS buffer was not treated with chemicals. For verification the correct activity of $r e c A$ promoter, the Escherichia coli K-12 strain containing pUA66 plasmid without the promoter was used as the control.

\section{Analytical Method for the Intensity of $g f p$ Gene Fluorescence (IF) Analysis}

After exposing bacteria cultures to the tested chemicals, the strains were washed with PBS buffer 
and the intensity of fluorescence of $g f p$ gene of bacteria cells suspension in PBS buffer was measured with the use of a spectrofluorometer (Glomax, Multi Detection System, Promega). The measurements were done at excitation and emission wavelengths of 485 and $507 \mathrm{~nm}$, respectively.

\section{Assessing SFI Values}

The specific fluorescence intensity (SFI) value measured with a spectrofluorometer is defined as culture fluorescence intensity (IF) divided by optical density (OD) at $600 \mathrm{~nm}$ for cell culture. SFI value was calculated according to the formula below [18-20] for monitoring the dynamic of $g f p$ expression after bacteria treatment with chemicals:

$$
S F I=\frac{I F}{O D}
$$

...where: SFI - Specific Fluorescence Intensity, IF - The raw fluorescence intensity of the strains at excitation and emission wavelengths of 485 and $507 \mathrm{~nm}, \mathrm{OD}$ - Optical Density at $600 \mathrm{~nm}$ of the strains.

\section{The Percentage Stimulation of Green Fluorescence} Protein Expression $\left(\mathrm{S}_{\text {gfpesp. }}\right)$ Value

The percentage stimulation of $g f p \quad\left(\mathrm{~S}_{g f p e x p}\right)$ was calculated according to the formula:

$$
\mathrm{S}_{\text {gfpexp. }}(\%)=\mathrm{I}_{\mathrm{TS}}(\%)-\mathrm{SFI}_{\mathrm{CS}}(\%)
$$

...where $\mathrm{I}_{\mathrm{TS}}(\%)$ - the increase of SFI values for tested compounds as a response to the level of $g f p$ expression in comparison with the control sample, $\mathrm{SFI}_{\mathrm{CS}}(\%)-\mathrm{SFI}$ for the control sample $=100 \%$.

\section{The Percentage Inhibition of Green Fluorescence} Protein Expression $\left(\mathrm{I}_{\text {gfpesp. }}\right)$ Value

The percentage inhibition of $g f p \quad\left(\mathrm{I}_{g f p e x p}\right)$ was calculated according to the formula:

$$
\mathrm{I}_{g f \text { exp. }}(\%)=\mathrm{SFI}_{\mathrm{CS}}(\%)-\mathrm{SFI}_{\mathrm{TS}}(\%)
$$

...where $\mathrm{SFI}_{\mathrm{CS}}(\%)-\mathrm{SFI}$ for the control sample $=100 \%$; $\mathrm{SFI}_{\mathrm{TS}}(\%)-\mathrm{SFI}$ for the tested sample.

\section{The Cytotoxic Effect Calculation}

The cytotoxic potency of analysed chemicals was calculated on the basis of GI (growth inhibition) value of $E$. coli K-12 treated with chemicals. The growth of bacteria strain treated with chemicals was monitored by the use of standard spectrophotometer analysis of optical density values at a wavelength of $600 \mathrm{~nm}$. The values of E. coli K-12 growth inhibition (GI) after 16 hours incubation with compounds was calculated according to the formula:

$$
\mathrm{GI}(\%)=\mathrm{OD}_{\mathrm{CS}}(\%)-\mathrm{D}_{\mathrm{ODTS}}(\%)
$$

...where: $\mathrm{OD}_{\mathrm{CS}}(\%)$ - optical density of control sample $=100 \% ; D_{\text {ODTS }}(\%)-$ the decrease in the value of optical density of bacteria samples treated with chemicals in relation to OD value of control sample (bacteria not treated with chemicals).

\section{The Fold Increase Values Calculations}

The dose-response data was expressed as fold increase (FI) of SFI value normalized with control and calculated according to the formula:

$$
\mathrm{FI}=\mathrm{SFI}_{\mathrm{TS}} / \mathrm{SFI}_{\mathrm{CS}}
$$

...where: FI - fold increase of SFI values; $\mathrm{SFI}_{\mathrm{TS}}-\mathrm{SFI}$ values of tested sample; $\mathrm{SFI}_{\mathrm{CS}}-\mathrm{SFI}$ values of control sample.

\section{The Genotoxic Effect Calculations}

The genotoxic potency of analyzed chemicals was calculated on the basis of SFI and FI values.

\section{Antimicrobial Activity Analysis of Tested Chemicals}

The chemicals (in water) were screened for their potential antibacterial activities in vitro against Staphylococcus epidermidis, E. coli, Klebsiella sp., Campylobacter sp., Bacillus sp., Enterobacter sp. and antifungal activities against Candida sp. (obtained from the American-type culture collection - ATCC). Antimicrobial activity was measured as a minimal inhibitory concentration (MIC) with Müeller Hinton agar (MHA). Serial two-fold dilutions of chemicals ranging from 10 to $350 \mu \mathrm{g} / \mathrm{mL}$ were prepared. After inoculation of microorganisms on MHA plates with certain tested chemical concentrations, plates were incubated at $30^{\circ} \mathrm{C}$ for 24 and 48 hours. Plates containing sterile water were used as controls. Kanamycin was used as positive control. A minimum of two repetitions were run for each assay. The MIC value was determined as the lowest concentration of chemicals, which completely inhibited bacterial and Candida sp. growth after $24 \mathrm{~h}$ and $48 \mathrm{~h}$ incubation.

\section{Statistical Analysis}

The experiment was conducted at least in three independent series $(n=6)$. Obtained data are expressed as a mean \pm standard deviation (SD). Data were analyzed using standard statistical analyses, including Student's test. $P$-values less than 0.05 were considered significant. 


\section{Results and Discussion}

CP is pro-drug, which is metabolised and excreted together with their metabolites from human body via urine and faeces. The residues of both compounds mainly end up in sewage systems and are found in wastewaters at concentrations of from $\mathrm{pg} / \mathrm{L}$ to $\mu \mathrm{g} / \mathrm{L}$. Nonetheless, biological activity and toxic effects of CP and vit $\mathrm{C}$ and their mixture are not well understood [47]. In the presented experiment we examined the influence of vitamin $\mathrm{C}$ as an antioxidant on biological activity of cyclophosphamide. CP, a bifunctional alkylating compound, is the most widely used oxazaphosphorine in the treatment of many neoplastic diseases. It has been shown that cyclophosphamide induces liver and lung damage as well as cardiotoxicity and nephrotoxicity. Therefore, cytoprotection of healthy tissues is needed. Vitamin $\mathrm{C}$ is one of the most popular vitamins in the human diet. Due to antioxidant and cytoprotective properties, this vitamin is recommended for many diseases, including cancer. High global consumption of vitamin $\mathrm{C}$ results in the presence of this compound and its metabolites in the environment, where they can affect living organisms and interact with other chemicals found in wastewater and water.

One novel cytoprotective method used in anticancer therapy is the combination of cytostatic delivery together with an antioxidant agent, which may be a potential therapeutic approach to reversing or arresting the progress of $\mathrm{CP}$ adverse effects [47-50]. For a long time, many reports have pointed to the important role of ascorbic acid in the prevention and treatment of cancer. The idea of using AA in anti-cancer therapy assumes that in high concentrations, in the presence of transition metal ions, it may have pro-oxidative activity. It is believed that the pharmacological concentrations of ascorbate may act cytotoxically on tumor cells, which is associated with the production of hydrogen peroxide during its autooxidation. The use of pharmacological doses of vitamin $\mathrm{C}$ in anti-cancer therapy remains controversial due to the differing results of several clinical trials. However, experiments on animal models have shown the inhibitory effect of ascorbate on the growth of cancerous tumors [51-53].

\section{Cytotoxicity Study}

In our study optical density (OD) measurements of E. coli $\mathrm{K}-12$ were the basic values for cytotoxic effect assessment and were expressed as a percentage of growth inhibition (GI) values (Fig. 1). Obtained data revealed the strongest cytotoxic potency for $\mathrm{CP}$ at concentrations of $3.5 \mu \mathrm{g} / \mathrm{ml}(\mathrm{GI}=55 \%)$, the mixture of CP $(350 \mu \mathrm{g} / \mathrm{ml})$ with vitamin C $(250 \mu \mathrm{g} / \mathrm{ml})$ ( $\mathrm{GI}=45 \%), \mathrm{CP}$ at the highest concentration of $350 \mu \mathrm{g} / \mathrm{ml}$ $(\mathrm{GI}=40 \%)$ and for the mixture of $\mathrm{CP}(35 \mu \mathrm{g} / \mathrm{ml})$ with vitamin $\mathrm{C}(250 \mu \mathrm{g} / \mathrm{ml})(\mathrm{GI}=35 \%)$. The E. coli $\mathrm{K}-12$ culture development was also efficiently inhibited after exposure to CP at a concentration of 35 and $0.35 \mu \mathrm{g} / \mathrm{ml}$.

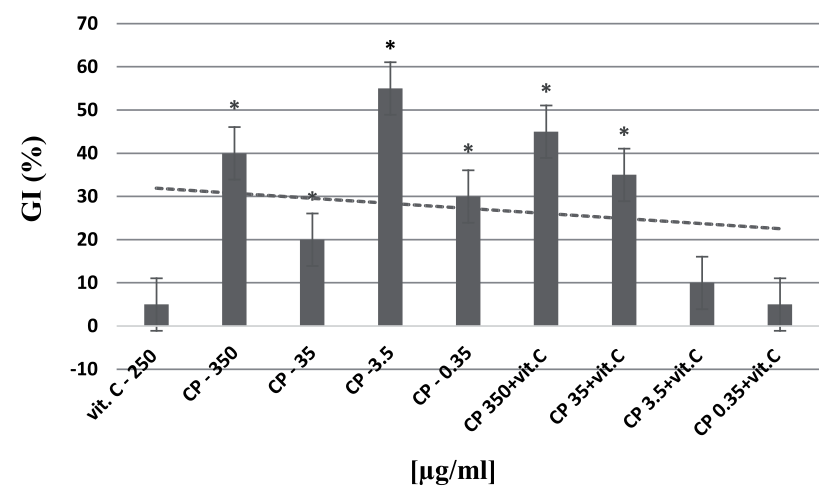

Fig. 1. Growth inhibition (GI) values of Escherichia coli K-12 strain after 16 hours treatment with cyclophosphamide, vitamin $\mathrm{C}$ and the mixture of the both chemicals; mean values $\pm \mathrm{SD}$; $\mathrm{n}=6$; * - significantly different from control $(\mathrm{p}<0.05)$.

\section{Genotoxicity Analysis}

Genotoxic properties of tested chemicals were calculated on the basis of the fold increase (FI) of SFI values normalized with control. Bacteria incubation with L-ascorbic acid at a concentration of $250 \mu \mathrm{g} / \mathrm{ml}$ resulted in a significant stimulation of SFI $\left(\mathrm{S}_{\text {gfpexp. }}=6.63 \%\right)$ values for 16 hours of Escherichia coli $\mathrm{K}-12 /$ recA-gfpmut 2 treatment compared to the control sample (Table 1, Figs 2-3). The exposure of bacteria cells to the highest concentration of CP $(350 \mu \mathrm{g} / \mathrm{ml})$ inhibited the gfpmut 2 gene expression by $14.6 \%$ in comparison to the control sample. The lower concentrations of CP (35 and $3.5 \mu \mathrm{g} / \mathrm{ml}$ ) caused the stimulation of gfpmut 2 gene expression by 8.04 and 5.07, respectively. Simultaneous co-administration of L-ascorbic acid with CP significantly differentiated the profile of gfpmut 2 gene expression in E. coli K-12 strain. The vitamin $\mathrm{C}$ at the concentration of $250 \mu \mathrm{g} / \mathrm{ml}$ in a mixture with CP $(35 \mu \mathrm{g} / \mathrm{ml})$ significantly increased the level of SFI value by $11.68 \%$ comparable to the control sample. With the application of other concentrations of $\mathrm{CP}(350,35$ and $3.5 \mu \mathrm{g} / \mathrm{ml})$ we noticed the lower influence of tested chemicals on SFI values, by $2.07,6.60$ and 2.66, respectively. Methylnitronitrosoguanidine (MNNG) - a known genotoxin at the concentration of $50 \mu \mathrm{M}$ - was used as the positive control. For this analyte, FI $=2.27$ was obtained for $16 \mathrm{~h}$ incubation time.

\section{Antimicrobial Activity Study}

The MIC values of tested chemicals against microorganisms are shown in Table 2. The CP exhibited better antimicrobial activity against Bacillus sp. and Enterobacter sp. (MIC $=175 \mu \mathrm{g} / \mathrm{mL}$ ) than ascorbic acid (MIC $>250 \mu \mathrm{g} / \mathrm{mL}$ ). The addition of AA to E. coli treated with $\mathrm{CP}$ reduced its bacteriostatic effect against Enterobacter sp. and Bacillus sp. For CP, AA, and the mixture of $\mathrm{CP}$ and $\mathrm{AA}$ the MIC values were above the values of positive control with kanamycin. 
Table 1. SFI, $\mathrm{S}_{g f p \text { exp., }} \mathrm{I}_{g f p \text { exp., }}$ FI values for 16 hours treatment of Escherichia coli K-12/recA-gfpmut 2 strain with different concentrations of cyclophosphamide (CP) and L-ascorbic acid at concentrations of $250 \mu \mathrm{g} / \mathrm{ml}$ in comparison to the control sample.

\begin{tabular}{|c|c|c|c|c|c|}
\hline N. & $\begin{array}{c}\text { Samples } \\
(\mu \mathrm{g} / \mathrm{ml})\end{array}$ & $\mathrm{SFI} \pm \mathrm{SD}$ & $\mathrm{S}_{g f \text { exp. }}$ & $\mathrm{I}_{g f p \text { exp. }}$ & FI \\
\hline 1. & L-ascorbic acid 250 & $3970 \pm 534^{\mathrm{a}}$ & 6.63 & - & 1.06 \\
\hline 2. & CP-350 & $3180 \pm 584^{\text {ab }}$ & - & 14.6 & -1.14 \\
\hline 3. & CP-35 & $4035 \pm 435^{\text {ac }}$ & 8.4 & - & 1.08 \\
\hline 4. & CP-3.5 & $3912 \pm 621^{\text {ac }}$ & 5.07 & - & 1.05 \\
\hline 5. & CP-0.35 & $3842 \pm 468^{\text {ac }}$ & 3.20 & - & 1.03 \\
\hline 6. & CP-350 + L-ascorbic acid 250 & $3800 \pm 526^{c}$ & 2.07 & - & 1.02 \\
\hline 7. & CP-35 + L-ascorbic acid 250 & $4158 \pm 534^{\text {ac }}$ & 11.68 & - & 1.11 \\
\hline 8. & CP-3.5 + L-ascorbic acid 250 & $3969 \pm 438^{c}$ & 6.60 & - & 1.06 \\
\hline 9. & CP-0.35 + L-ascorbic acid 250 & $3822 \pm 437^{c}$ & 2.66 & - & 1.02 \\
\hline 10. & rec $A:: g f p$ MNNG (positive control) $(50 \mu \mathrm{M})$ & $8456 \pm 774$ & 227.13 & - & 2.27 \\
\hline 11. & Control (recA-gfp) & $3723 \pm 456$ & - & - & - \\
\hline 12. & Promoter-less: E. coli K-12 gfp & $2.80 \pm 0.76$ & - & - & - \\
\hline
\end{tabular}

Mean values $\pm S D ; n=6$; a - significantly different from control $(\mathrm{p}<0.05)$; $\mathrm{b}$ - significantly different from L-ascorbic acid group $(\mathrm{p}<0.05) ; \mathrm{c}$ - significantly different from CP $350 \mu \mathrm{g} / \mathrm{ml}$ group $(\mathrm{p}<0.05)$

Simultaneous interaction of $\mathrm{CP}$ and vitamin $\mathrm{C}$ differentiated the biological activity of $\mathrm{CP}$ against Bacillus sp. and Enterobacter sp.

In this work we analyzed the influence of vitamin $\mathrm{C}$ on cyto-, genotoxic and antimicrobial effects of cyclophosphamide - a known anticancer drug. We used the $E$. coli strain with plasmid transcriptional fusion of recA promoter and gfpmut2 gene as the model.

$\mathrm{CP}$ is an alkylating agent with an active metabolite leading to DNA cross-linking. Although CP has proven to be a promising and effective chemotherapeutic agent, the International Agency for Research on Cancer (IARC) in 1991 designated it as carcinogen. The molecular mechanism of CP action in a cell is associated with gene mutations, DNA damage, chromosomal aberrations, micronuclei, and sister chromatid exchange in cultured cells of humans, animals, and microorganisms. Mutations induced by $\mathrm{CP}$ have been shown to be positive in Salmonella typhimurium and in Saccharomyces cerevisiae [53].

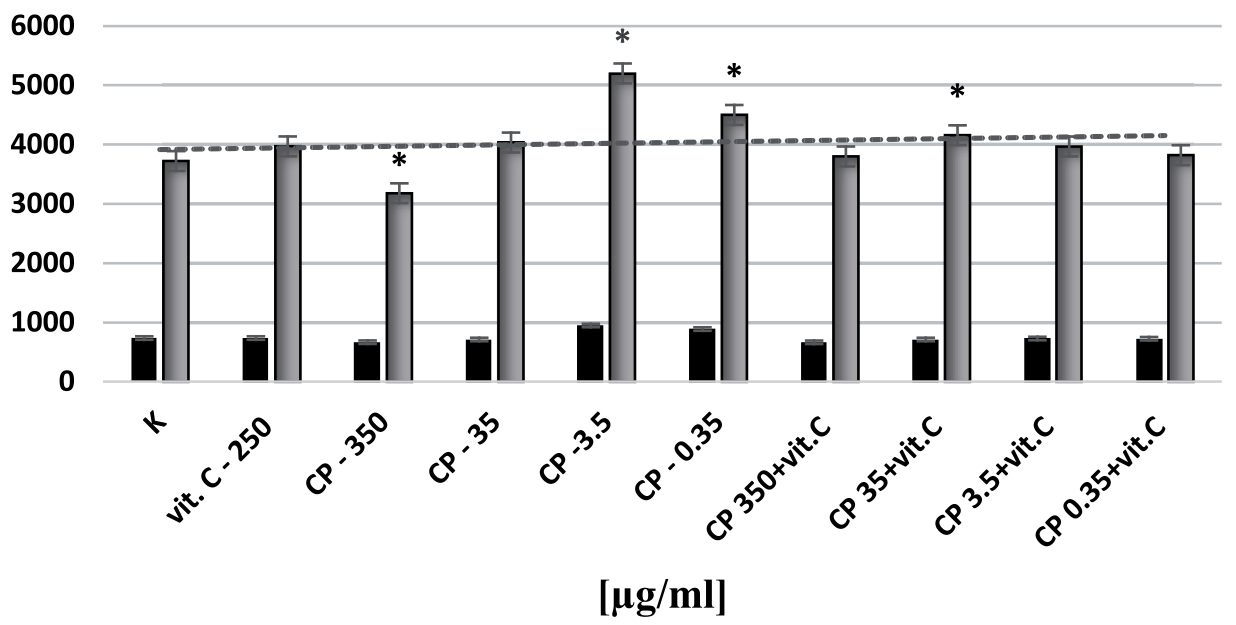

FI* (fluorescence intensity)

Fig. 2. Fluorescence intensity $\left(\mathrm{FI}^{*}\right)$ and SFI values of Escherichia coli K-12/recA-gfpmut2 strain after 16 hours treatment with cyclophosphamide, vitamin $\mathrm{C}$ and the mixture of the both chemicals; mean values $\pm \mathrm{SD} ; \mathrm{n}=6$; * - significantly different from control $(\mathrm{p}<0.05)$. 


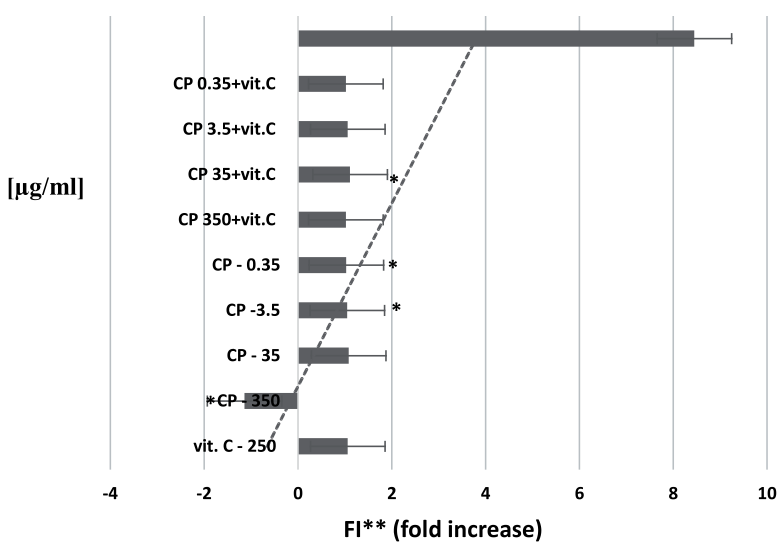

Fig. 3. Fold increase (FI**) of SFI values normalized with control of Escherichia coli K-12/recA-gfpmut2 strain after 16 hours treatment with cyclophosphamide, vitamin $\mathrm{C}$ and the mixture of the both chemicals; mean values $\pm \mathrm{SD} ; \mathrm{n}=6$; * - significantly different from control $(\mathrm{p}<0.05)$.

Biodegradation is the main microbial process of decomposition of pharmaceutical pollutants in simpler compounds. In environmental compartments such as wastewaters, pharmaceutical residues exist in a form of mixtures of parental drug and its transformation products (TPs). Previous studies have detected that the mixtures of TPs could have a higher toxic potency than the parent drug and can affect living organisms. Moreover, these chemicals are usually biologically active even at low concentrations, and they have the ability to form complexes with other chemical compounds found in wastewaters and surface waters. It raises the need of determination of the cyto- and genotoxic activity and safety profiles of not only the drugs but also their TPs and their mixtures $[1,22]$.

In the presented experiment we showed different cytotoxic sensitivities of the E. coli $\mathrm{K}-12$ strain to $\mathrm{CP}$ and vitamin $\mathrm{C}$ after $16 \mathrm{~h}$ incubation in comparison to the control sample. The strongest cytotoxic potency was revealed for $\mathrm{CP}$ at a concentration of $3.5 \mu \mathrm{g} / \mathrm{ml}$. The mixture of CP $(350 \mu \mathrm{g} / \mathrm{ml})$ with vitamin $\mathrm{C}(250 \mu \mathrm{g} / \mathrm{ml})$ (GI $=45 \%$ ), CP at the highest concentration of $350 \mu \mathrm{g} / \mathrm{ml}$ (GI $=40 \%)$ and for the mixture of CP $(35 \mu \mathrm{g} / \mathrm{ml})$ with vitamin C $(250 \mu \mathrm{g} / \mathrm{ml})(\mathrm{GI}=35 \%)$. The Escherichia coli
K-12 culture development was also efficiently inhibited after exposure to $\mathrm{CP}$ at a concentration of 35 and $0.35 \mu \mathrm{g} / \mathrm{ml}$. We expected a more linear value, dependent on the $\mathrm{CP}$ concentration used and the cytotoxic response of $E$. coli. The biochemical phenomenon of unexpected effect of very low doses of some chemicals is called "non-monotonic response" and it is not fully explained. Sandyik et al. explained that the low concentration of chemicals (in this case $\mathrm{CP}$ ) are too low to activate the stress signaling and transcription of chaperone proteins. As we know, these proteins can protect living cells against stress conditions. But from the other side these concentrations are sufficient to exert a destructive effect on cells, e.g. in chemical processes such as ROS generation. At higher concentrations, SOS signaling pathways are activated to protect against the effects of stressors [54-55].

In our research we noticed that, influence of vit. $\mathrm{C}$ on the cytotoxic and genotoxic activity of $\mathrm{CP}$ is strictly dependent on the CP dose used. At higher doses of CP (350 and $35 \mu \mathrm{g} / \mathrm{ml})$, vit. C enhances the cytotoxic activity of $\mathrm{CP}$, while in its lower concentrations (3.5 and $0.35 \mu \mathrm{g} / \mathrm{ml}$ ) it weakens the cytotoxic effect of cyclophosphamide. The main CP cytotoxicity mechanism results from the generation of oxidative stress in cells [50-52]. In our experiment we showed that vitamin $\mathrm{C}$, depending on the $\mathrm{CP}$ concentration used, enhances or reduces the cytotoxicity of CP. Probably, the mechanism responsible for this effect is connected with the heterogeneous nature of vitamin C. Studies of recent years have shown that this vitamin can behave differently in various concentrations used [52-53].

The results obtained by us indicate the strongest $\mathrm{CP}$ interaction to be at the concentrations of 3.5 and $0.35 \mu \mathrm{g} / \mathrm{ml}$ for the expression of the gene gfpmut 2 in E. coli K-12. Vitamin C at a concentration of $250 \mu \mathrm{g} / \mathrm{ml}$ is significantly less affected by the level of expression of the $g f p$ gene. The administration of vitamin $\mathrm{C}$ with cyclophosphamide slightly modulated the genotoxic effect of the cytostatics. The strongest effect of vitamin $\mathrm{C}$ on $g f p$ expression was disturbed in the lowest CP concentrations used. In our last work [33], we obtained a similar effect of vitamin $\mathrm{C}$ activity, where this vitamin differentiated the toxicity of doxorubicine and its

Table 2. MIC values of tested chemicals against microorganisms: $\mathrm{H}$ - higher than 350 or $250 \mu \mathrm{g} / \mathrm{ml}$; $\mathrm{CP}$ - cyclophosphamide; AA - L-ascorbic acid, + growth of bacteria culture.

\begin{tabular}{|c|c|c|c|c|c|c|c|}
\hline $\begin{array}{c}\text { Chemicals } \\
(\mu \mathrm{g} / \mathrm{ml})\end{array}$ & $\begin{array}{c}\text { S. epidermidis } \\
(\text { Gram }+)\end{array}$ & $\begin{array}{c}\text { E. coli } \\
(\text { Gram- })\end{array}$ & $\begin{array}{c}\text { Klebsiella } \text { sp. } \\
(\text { Gram- }\end{array}$ & $\begin{array}{c}\text { Campylobacter sp. } \\
(\text { Gram- })\end{array}$ & $\begin{array}{c}\text { Bacillus sp. } \\
(\text { Gram }+)\end{array}$ & $\begin{array}{c}\text { Enterobacter sp. } \\
(\text { Gram- })\end{array}$ & $\begin{array}{c}\text { Candida sp. } \\
(\text { Gram }+)\end{array}$ \\
\hline $\mathrm{CP}$ & $\mathrm{H} 350$ & $\mathrm{H} 350$ & $\mathrm{H} 350$ & $\mathrm{H} 350$ & $=175$ & $=175$ & $\mathrm{H} 350$ \\
\hline $\mathrm{AA}$ & $\mathrm{H} 250$ & $\mathrm{H} 250$ & $\mathrm{H} 250$ & $\mathrm{H} 250$ & $\mathrm{H} 250$ & $\mathrm{H} 250$ & $\mathrm{H} 250$ \\
\hline $\begin{array}{c}\mathrm{CP} \\
(350 \mu \mathrm{g} / \mathrm{ml}) \\
+\mathrm{AA}(250 \mu \mathrm{g} / \mathrm{ml})\end{array}$ & + & + & + & + & + & + & + \\
\hline $\begin{array}{c}\text { Kanamycin } \\
(\text { positive control })\end{array}$ & 100 & 50 & 100 & 50 & 100 & 100 & 100 \\
\hline
\end{tabular}


complexes with metals. In this work we also showed that the biological activity of vitamin $\mathrm{C}$ is closely correlated with the dose of DOX and its complexes with metals used [33].

Microbial biosensors are widely used and recommended for assessing biological impact and genotoxicity. Compared with conventional chromatographic methodologies such as gas chromatography (GC) or high-performance liquid chromatography (HPLC), which are tedious and not portable, the use of biosensors is gaining more attention as they offer rapid and on-site/point-of-care monitoring of even trace levels of genotoxins [31-39, 56].

In our research we noticed that with the use of genotoxin-sensitive Escherichia coli $\mathrm{K}-12 /$ recA-gfpmut2 bioreporter strain with a genotoxic activity of $\mathrm{CP}$ at lower concentrations (3.5 and $0.35 \mu \mathrm{g} / \mathrm{ml}$ ), vitamin $\mathrm{C}$ at a concentration of $250 \mu \mathrm{g} / \mathrm{ml}$ and a mixture of both drugs at the each concentration of cyclophosphamide, ranging from 350 to $0.35 \mu \mathrm{g} / \mathrm{ml}$ mixed with $250 \mu \mathrm{g} / \mathrm{ml}$ of vit. C. Cyclophosphamide (CP) belongs to a group of alkylating agents and its primary mode of action is based on their interaction with DNA, resulting in repressed cell division. $\mathrm{CP}$ is a prodrug and in human and animal model cells, the genotoxic effect of CP may be due to its metabolic activation by the hepatic microsomal cytochrome P450 mixed functional oxidase system via two different pathways. In the first pathway, CP is catalyzed by cytochrome P-4502 B and P-4502C enzymes to form the DNA cross-linking agent, phosphoramide mustard, and the toxic metabolite acrolein (AC). The second pathway involves a CYP3A4mediated $\mathrm{N}$ - dechloroethylation of $\mathrm{CP}$ to form the inactive metabolite, 3-dechloroethylcyclophosphamide (DECP), and the toxic by-product chloroacetaldehyde. $\mathrm{CP}$ metabolites can generate free radicals that can lead to oxidative stress. In our experiment we used a procaryotic model of $E$. coli strain. Thus, CP metabolism is probably different in bacteria cells in comparison to human cells. Maybe, as a result of CP biochemical changes, other intermediate metabolites are formed, which can also generate free radical production [47-50, 57].

It was revealed that anticancer chemotherapy changes the fecal microbiota in patients. In mice, CP treatment increases the potentially pathogenic bacteria counts and reduces the intestinal tight junctions and adherens junctions. Recent studies have shown a close correlation between the composition and activity of the human digestive tract microbiome and the efficiency of CP anti-cancer activity. Iida at al., 2013 [58], presented a complex correlation between therapy efficacy of $\mathrm{CP}$ and gut microbiota as well as immune system in mice models. Additionally, the authors found that the gut barrier was disrupted and the digestive system problems were developed in cancer patients undergoing chemotherapy with CP. This suggests that a link of CP to gut microbiota also exists. So, it is very important to understand how $\mathrm{CP}$ affects intestinal microbiota and immune functions. Similarly, in the work of $\mathrm{Xu}$ and Zghang 2015 [59], authors revealed that CP reduced the diversity and shifted the fecal microbiota composition in mice. Specifically, CP treatment decreased the proportion of Bacteroidetes while increasing the proportion of Firmictutes in the microbial community. Most importantly, specific microbiota signatures belonging to Bacteroides acidifaciens, Streptococcaceae and Alistipes were also identified, which would provide new insight into the efficacy and side effects in clinical usage of CP. This should be helpful for further demonstrations of $\mathrm{CP}$ action mechanisms, the development of personalized therapy strategies, and predicting potential side effects related to various treatment regimens of CP [59].

Recent data have revealed that therapy efficacy of $\mathrm{CP}$ is gut microbiota-dependent. So, it is very important to understand how $\mathrm{CP}$ affects intestinal microbiota and immune function. Anticancer chemotherapeutics often cause mucositis (a debilitating mucosal barrier injury associated with bacterial translocation) and neutropenia - two complications that require treatment with antibiotics, which in turn can result in dysbiosis. Some antineoplastic agents mediate part of their anticancer activity by stimulating anticancer immune responses. Cyclophosphamide (CP), a prominent alkylating anticancer agent, induces immunogenic cancer cell death, subverts immunosuppressive T cells and promotes Th1 and Th17 cells controlling cancer outgrowth [59].

In our experiment the use of a simultaneous treatment of $E$. coli strain with $\mathrm{CP}$ and vit. C modulate the cytotoxic and genotoxic potency of both drugs. In our work, we noticed the dose-dependent effect of the vitamin $\mathrm{C}$ in mixture with $\mathrm{CP}$ in Escherichia coli $\mathrm{K}-12$ in comparison to the monoterapeutic impact of drugs. We noticed that in higher concentrations of CP (350 and $35 \mu \mathrm{g} / \mathrm{ml}$ ), vitamin $\mathrm{C}$ strengthens the cytotoxic effect of $\mathrm{CP}$ and weakens in the lower ones. We have also observed a similar scheme of the effects of both drugs by analyzing their genotoxic potency and their mixture in E. coli strain. It is known that vitamin $\mathrm{C}$ has mutagenic and clastogenic effects. The mode of biological action of this vitamin is dependent on its concentration [60-63]. Nefić 2008 [64] has described in her work the genotoxic effects of vitamin $\mathrm{C}$ in different test systems. Vitamin $\mathrm{C}$ possesses mutagenic activity, inducing DNA strand breakage and chromosome aberrations, increasing the frequency of sister-chromatid exchanges (SCES) in cells and increasing the number of somatic mutations. However, vitamin $\mathrm{C}$ is not an active mutagen itself. Oxy radicals, appearing during the oxidation of the vitamin, are implicated in toxic actions of vitamin $\mathrm{C}$ in vitro $[33$, 64].

Antimicrobial studies of $\mathrm{CP}$ and vit $\mathrm{C}$ revealed the highest activity of $\mathrm{CP}$ against Enterobacter sp. and Bacillus sp. The antimicrobial activity of CP was shown against Staphylococcus aureus, Staphylococcus epidermidis, Streptococcus sanguis, Escherichia coli, Pseudomonas aeruginosa and Candida albicans. 
Additionally, some authors have revealed that there was a strong effect of $\mathrm{CP}$ on the composition of the natural microflora of the human gastrointestinal tract. Oncological therapy with cyclophosphamide led to dysbiosis and excessive multiplication of pathogenic microorganisms, which affects the effectiveness of treatment of the patient and constitutes a threat to his or her survival. It is considered that the major mechanism of antimicrobial activity of cyclophosphamide is its ability to induce DNA damage and the generation of free radicals or reactive oxygene species (ROS) [58-59].

Numerous scientific experiments have demonstrated the microbiological activity of vitamin $\mathrm{C}$ against various bacteria and viruses. Moreover, it was found that vit $\mathrm{C}$ is effective in treating infections that cause whooping cough, diphtheria, tetanus, polio or infections due to AIDS. Ascorbic acid presents a double-faced character in that it exhibits a pro-oxidant activity arising from its routine antioxidant property. The molecular mechanisms of its action is vit C's ability to generate free radicals. These very active particles interact with DNA, inducing its damage by causing breaks in phosphodiester backbone and modification of DNA bases [60-62].

In our experiment, we detected that simultaneous interaction of cyclophosphamide and vitamin $\mathrm{C}$ differentiated the microbial activity of $\mathrm{CP}$ against Bacillus sp. and Enterobacter sp. Vitamin C, in addition with $\mathrm{CP}$, decreased cyclophosphamide-toxicity against Enterobacter sp. and Bacillus sp. Vitamin $\mathrm{C}$ is an antioxidant. Therefore, any effects of vitamin $\mathrm{C}$ may be most prominent under conditions when oxidative stress is elevated. These water-soluble vitamins in action with $\mathrm{CP}$ decreased the level of $\mathrm{CP}$-induced oxidative stress and it led to the reduction of the cytotoxic effect of $\mathrm{CP}$ against tested microorganisms [63].

Moreover, it is worth mentioning that some of the tested microorganisms belong to natural human microflora of the digestive tract and skin (E. coli, Enterobacter, Staphylococcus epidermidis, Candida sp.). Microorganisms of the human digestive tract are accustomed to the presence of vitamin $\mathrm{C}$ consumed on a daily basis, which they can metabolize, hence a greater tolerance for higher doses of vitamin C. This may explain the lower L-ascorbic acid cytotoxic effect on tested microorganisms [58-59].

\section{Conclusions}

In wastewaters and surface waters, drugs and their TPs are mainly in the form of mixtures. Further investigations on the ecotoxic potential and the impact on living organisms of these mixtures are required [65]. In our studies, we have shown that mixtures of $\mathrm{CP}$ and vitamin $\mathrm{C}$ in the highest $\mathrm{CP}$ concentrations are more toxic to the E. coli strain compared to parent chemicals. In addition, we also found that drug mixtures, especially at the highest $\mathrm{CP}$ concentrations, more strongly stimulate the $r e c A$ promoter and $g f p$ gene expression comparable to the drugs alone. We showed that Escherichia coli $\mathrm{K}-12 / r e c A-g$ fpmut2 microbial biosensor is a useful tool in assessing the impact of cyclophosphamide and L-ascorbic acid residues and their mixtures on living bacteria cells. A stronger impact and toxicity of the mixtures of both tested chemical compounds were found in comparison to parent chemicals.

\section{Acknowledgements}

Authors are very grateful to Prof. Uri Alon, Department of Molecular Cell Biology and Department of Physics of Complex Systems, Weizmann Institute of Science Rehovot, Israel, for providing bacteria strains.

This work was financially supported by the National Science Centre of Poland under research project number 2018/29/B/NZ9/01 997.

\section{Conflict of Interest}

The authors declare that they have no conflict of interest.

\section{References}

1. ČESEN M., KOSJEK T., LAIMOU-GERANIOU M., KOMPARE B., ŠIROK B., LAMBROPOLOU D., HEATH E. Occurrence of cyclophosphamide and ifosfamide in aqueous environment and their removal by biological and abiotic wastewater treatment processes. Scienc. Total Environm. 527-528, 4653, 2015.

2. GŸRGEN S., ELMAS C., KAPLANOGLU G. T., OZER C. Chemoprotective effect of ascorbic acid, $\alpha$-tocopherol, and selenium on cyclophosphamide-induced toxicity in the rat ovarium, Nutrition 29 (5), 777, 2018.

3. GUIDA M., CASTALDI M.A., ROSAMILIO R., GIUDICE V., ORIO F., SELLERI C. Reproductive issues in patients undergoing hematopoietic stem cell transplantation: an update, J. Ovarian Res. 9 (1), 7279, 2016.

4. MORGAN S., ANDERSON R.A., GOURLEY C., WALLACE W.H., SPEARS N. How do chemotherapeutic agents damage the ovary? Hum. Reprod. Update 18 (5), 525, 2012.

5. BLUMENFELD Z. Chemotherapy and fertility, Best. Pract. Res. Clin. Obstet. Gynaecol. 26 (3), 379, 2012.

6. GARRIDO-COLINO C., LASSALETTA A., VAZQUEZ M.Á., ECHEVARRIA A., GUTIERREZ I., ANDIÓN M., BERLANGA P Current situation on fertility preservation in cancer patients in Spain: level of knowledge, information, and professional involvement, An. Pediatr. 87 (1), 1, 2016

7. KALLENBERG C.G. Pro: cyclophosphamide in lupus nephritis, Nephrol. Dial. Transplant. 31 (7), 1047, 2016.

8. YASUDA S., KONO M., SHIMAMURA S., KURITA T., ODANI T., ATSUMI T. Prognosis and progress in immunotherapies for organ involvements in systemic autoimmune diseases, Nihon Rinsho Meneki Gakkai Kaishi 39 (1), 8, 2016. 
9. KIM J., CHAN J.J. Cyclophosphamide in dermatology, Australas. J. Dermatol. 58 (1), 5, 2016.

10. QIN W.S., DENG Y. H., CUI F.C. Sulforaphane protects against acrolein-induced oxidative stress and inflammatory responses: modulation of Nrf-2 and COX-2 expression, Arch. Med. Sci. 12 (4), 871, 2016.

11. SUN Y., ITO S., NISHIO N., TANAKA Y., CHEN N., LIU L., ISOBE K. Enhancement of the acrolein-induced production of reactive oxygen species and lung injury by GADD34, Oxid. Med. Cell Longev. 15 (3), 1703, 2015.

12. HORIYAMA S., HATAI M., TAKAHASHI Y., DATE S., MASUJIMA T., HONDA C., ICHIKAWA A., YOSHIKAWA N., NAKAMURA K., KUNITOMO M., TAKAYAMA M. Intracellular metabolism of alpha, betaunsaturated carbonyl compounds, acrolein, crotonaldehyde and methyl vinyl ketone, active toxicants in cigarette smoke: participation of glutathione conjugation ability and aldehydeketone sensitive reductase activity, Chem. Pharm. Bull. 64 (6), 585, 2016.

13. DETTI L., UHLMANN R.A., LU M., DIAMOND M.P., SAED G.M., FLETCHER N.M., ZHANG J., WILLIAMS L.J. Serum markers of ovarian reserve and ovarian histology in adult mice treated with cyclophosphamide in pre-pubertal age, J. Assist. Reprod. Genet. 30 (11), 1421, 2013.

14. CHEN X.Y., XIA H.X., GUAN H.Y., LI B., ZHANG W. Follicle loss and apoptosis in cyclophosphamide-treated mice: what's the matter? Int. J. Mol. Sci. 17 (6), 836, 2016.

15. SONG D., ZHONG Y., QIAN C., ZOU Q., OU J., SHI Y., GAO L., WANG G., LIU Z., LI H., DING H., WU H., WANG F., WANG J., LI H. Human umbilical cord mesenchymal stem cells therapy in cyclophosphamideinduced premature ovarian failure rat model, Biomed. Res. Int. 4 (3), 2517, 2016.

16. JIANG S., ZHAO J., QI H., LI X., ZHANG S., SONG D. W., YU CH., GAO J. Accelerated ovarian aging in mice by treatment of busulfan and cyclophosphamide, J. Zhejiang Univ. Sci. B 14 (4), 318, 2013.

17. O'TOOLE T.E., ZHENG Y., HELLMANN J., CONKLIN D.J., BARSKI O., BHATNAGAR A. Acrolein activates matrix metalloproteinases by increasing reactive oxygen species in macrophages, Toxicol. Appl. Pharmacol. 236 (2), 194, 2009.

18. MOGHE A., GHARE S., LAMOREAU B., MOHAMMAD M., BARVE S., MCCLAIN C., JOSHI-BARVE S. Molecular mechanisms of acrolein toxicity: relevance to human disease, Toxicol. Sci. 143 (2), 242, 2015.

19. SHEWEITA S.A., EL-HOSSEINY L.S., NASHASHIBI M.A. Protective effects of essential oils as natural antioxidants against hepatotoxicity induced by cyclophosphamide in mice, PLoS One 11 (11), 165, 2016.

20. GIANARIS A., LIU N.K., WANG X.F., OAKES E., BRENIA J., GIANARIS T., RUAN Y., DENG L.X., GOETZ M., VEGA-ALVAREZ S., LU QB., SHI R., XU X.M. Unilateral microinjection of acrolein into thoracic spinal cord produces acute and chronic injury and functional deficits, Neuroscience 326 (2), 84, 2016.

21. STANKIEWICZ A., SKRZYDLEWSKA E., MAKIELA $M$. Effects of amifostine on liver oxidative stress caused by cyclophosphamide administration to rats, Drug Metabol. Drug Interact. 19 (2), 67, 2002.

22. BUERGE I.J., BUSER H.-R., POIGER T., MÜLLER M.D. Occurrence and fate of the cytostatic drugs cyclophosphamide and ifosfamide in wastewater and surface waters $\uparrow$. Environ. Sci. Technol. 40, 7242, 2006.
23. GONZÁLEZ M.J., ROSARIO-PÉREZ G., GUZMÁN A.M., MIRANDA-MASSARI J.R., DUCONGE J., LAVERGNE J., FERNANDEZ N., ORTIZ N., QUINTERO A., MIKIROVA N., RIORDAN N.H., RICART C.M. Mitochondria, energy and cancer: the relationship with ascorbic acid, J. Orthomol. Med. 25 (7), 29, 2010.

24. GUERRIERO E., SORICE A., CAPONE F., NAPOLITANO V., COLONNA G., STORTI G., CASTELlO G., COSTANTINI S. Vitamin $\mathrm{C}$ effect on mitoxantrone - induced cytotoxicity in human breast cancer cell lines, PloS One 9 (5), 115, 2014.

25. MATA A.M., CARVALHO R M., DE ALENCAR M.R. Ascorbic acid in the prevention and treatment of cancer, Rev. Assoc. Med. Bras. 62 (3), 680, 2016.

26. [CAMARENA V., WANG G. The epigenetic role of vitamin $\mathrm{C}$ in health and disease, Cell. Mol. Life. Sci. 73 (6), 1645, 2016

27. GWENDOLYN VAN GORKOM N.Y., THEODOROU A.A., KYPAROS A., DIPLA K., ZAFEIRIDIS A. PANAYIOTOU G., VRABAS I.S., NIKOLAIDIS M.G. Influence of vitamin $\mathrm{C}$ on lymphocytes: an overview, Antioxidants (Basel) 7 (4), 41, 2018.

28. MASTRANGELO D., PELOSI E., CASTELli G., LOCOCO F., TESTA U. Mechanisms of anti-cancer effects of ascorbate: Cytotoxic activity and epigenetic modulation, Blood Cells, Molec. Disea. 69 (1), 57, 2018.

29. AWAD J., STOTZ H.U., FEKETE A., KRISCHKE M., ENGERT C., HAVAUX M., BERGER S., MUELLER M.J. 2-Cysteine peroxiredoxins and thylakoid ascorbate peroxidase create a water-watercycle that is essential to protect the photosynthetic apparatus under high light stress conditions, Plant Physiol. 167, 1592, 2015.

30. DIETZ K.J. Thiol-based peroxidases and ascorbate peroxidases: why plants rely on multiple peroxidase systems in the photosynthesizing chloroplast? Mol. Cells 39 (2), 20, 2016.

31. MATEJCZYK M., LEWANDOWSKI W., ROSOCHACKI S. J. E. coli K-12 recA::gfp microbial biosensor used for screening of anticancer and antidiabetic pharmacist residues, Desal. Water Treatm. 57 (3), 1582, 2016.

32. MATEJCZYK M., ŚWISŁOCKA R., LEWANDOWSKI W. Cytotoxic, genotoxic and antimicrobial activity of caffeic and rosmarinic acids and their lithium, sodium and potassium salts as potential anticancer compounds, Advan. Med. Sci. 63 (8), 14, 2018

33. MATEJCZYK M., ŚWIDERSKI G., ŚWISŁOCKA R., LEWANDOWSKI W. Seleno-L-Methionine and L-ascorbic acid differentiate the biological activity of doxorubicin and its metal complexes as a new anticancer drugs candidate, J. Trace Elem. Medic.Biol. 48, 141, 2018.

34. ÖBEK E., HASAR H., TATAR S. Y., KARATAS F. Determination of some vitamins in different matrixes in a municipal wastewater treatment plant. Pakis. J Nutrition 4 (2), 407, 2005.

35. VOLLMER A.C., BELKIN S., SMULSKI D.R., VAN DYK T.K., LAROSSA R.A. Detection of DNA damage by use of Escherichia coli carrying recA::lux, uvrA::lux, or alkA::lux reporter plasmids, Appl. Environ. Microbiol. 63 (4), 2566, 1997.

36. YAGUR-KROLL S., BELKIN S. Upgrading bioluminescent bacterial bioreporter performance by splitting the lux operon, Anal. Bioanal. Chem. 400 (3), 1071, 2011

37. YAGUR-KROLL S., BILIC B., BELKIN S. Strategies for enhancing bioluminescent bacterial sensor performance by 
promoter region manipulation, Microb. Biotechnol. 3, 300, 2010.

38. MELAMED S., LALUSH C., ELAD T., YAGUR-KROLL S., BELKIN S., PEDAHZUR R. A bacterial reporter panel for the detection and classification of antibiotic substances, Microb. Biotechnol. 5 (1), 536, 2012.

39. HASSAN S. H. A., VAN GINKEL S.W., HUSSEIN M.A., ABSKHARON R., OH S.E. Toxicity assessment using different bioassays and microbial biosensors, Environ. Internat. 92-93, 106, 2016.

40. PTITSYN L.R., HORNECK G., KOMOVA O., KOZUBEK S., KRASAVIN E.A., BONEV M. A biosensor for environmental genotoxin screening based on an SOS lux assay in recombinant Escherichia coli cells, Appl. Environ. Microbiol. 63, 4377, 1997.

41. KOSTRZYNSKA M., LEUNG K.T., LEE H., TREVORS J.T. Green fluorescent protein-based biosensor for detecting SOS - inducing activity of genotoxic compounds, J. Microbiol. Methods. 48 (6), 43, 2002.

42. YAGUR-KROLL Y., LALUSH C., ROSEN R., BACHAR N., MOSKOVITZ Y., BELKIN S. Escherichia coli bioreporters for the detection of 2,4-dinitrotoluene and 2,4,6-trinitrotoluene, Appl. Microbiol. Biotechnol. 98 (4), 885, 2014.

43. BECHOR O., SMULSKI D.R., VAN DYK T.K., LAROSSA R.A., BELKIN S. Recombinant microorganisms as environmental biosensors: pollutants detection by Escherichia coli bearing fabA'::lux fusions, J. Biotechnol. 94 (8), 125, 2002.

44. ELAD T., BENOVICH E, MAGRISSO S, BELKIN S. Toxicant identification by a luminescent bacterial bioreporter panel: application of pattern classification algorithms, Environ. Sci. Technol. 42 (4), 8486, 2008.

45. ELAD T., BELKIN S. Broad spectrum detection and "barcoding" of water pollutants by a genome-wide bacterial sensor array, Water Res. 47 (3), 3782, 2016.

46. ELAD T., BELKIN S. Reporter gene assays in ecotoxicology, In vitro environmental toxicology concepts, application and assessment, 3 (1), 135, 2016.

47. KOSJEK T., HEATH E. Occurrence, fate and determination of cytostatic pharmaceuticals in the environment, Trends Anal. Chem. 30 (7), 1065, 2011.

48. STANKIEWICZ A., SKRZYDLEWSKA E. Effect of amifostine on lung oxidative stress after cyclophosphamide therapy, Bull. Vet. Pulawy 46, 87-96, 2002.

49. STANKIEWICZ A., SKRZYDLEWSKA E. Amifostine Antioxidant Effect on Serum of Rats Treated with Cyclophosphodamide, A. Stankiewicz, E. Skrzydlewska. Pol. J. Environ. Stud. 14 (3), 341, 2005.

50. SINGH T., KASTURE S., MOHANTY B., JALIWALA Y., KARCHULI M.S., AGARWAL A., YADAV Y. Cyclophosphamide-induced oxidative stress in brain: Protective effect of Garcinia indica fruit extract, Int. J. Pharm. Life Sci. 2, 1035, 2011.

51. LIN J.L., HUANG Y.H., SHEN Y.C., HUANG H.C., LIU P.H. Ascorbic acid prevents blood-brain barrier disruption and sensory deficit caused by sustained compression of primary somatosensory cortex, J. Cereb. Blood. Flow. Metab. 30 (4), 1121, 2010

52. KAWADA H., SAWANOBORI M., ANEKO M. T., WASADA I., MIYAMOTO M. Phase I clinical trial of intravenous L-ascorbic acid following salvage chemotherapy for relapsed B-cell non-Hodgkin's lymphoma. Tokai. J. Exp. Clin. Med. 39, 111, 2014.

53. SAMARTH S.M., KHAN T., SRIVAS S., MISHRA P.K., TIWARI R.R. Evaluation of cyclophosphamideinduced genotoxicity and cytotoxicity in cultured human lymphocytes, J. Radiat. Cancer Res. 1, 28, 2018.

54. SANDVIK E.L., FAZEN C.H., HENRY T.C., MOK W.W., BRYNILDSEN M.P. Non-monotonic survival of Staphylococcus aureus with respect to ciprofloxacin concentration arises from prophage dependent killing of persisters, Pharmaceuticals 8 (5), 778, 2015.

55. FAGIN D. Toxicology: The learning curve. Nature 490, 462 , 2012.

56. ELAD T., SEO H.B., BELKIN S., GU M.BHighthroughput prescreening of pharmaceuticals using a genomewide bacterial bioreporter array, Biosensors Bioelectron. 68 (5), 699, 2015.

57. CESEN M., ELERŠEK T., NOVAK M., ŽEGURA B., KOSJEK T., FILIPIČ M., HEATH E. Ecotoxicity and genotoxicity of cyclophosphamide, ifosfamide, their metabolites/transformation products and their mixtures, Environm. Pollut. 210 (5), 192, 2016.

58. IIDA N., DZUTSEV A., STEWART C.A., SMITH L., BOULADOUX N. Commensal bacteria control cancer response to therapy by modulating the tumor microenvironment, Science 342 (6), 967, 2013.

59. XU X., ZHANG X. Effects of cyclophosphamide on immune system and gut microbiota in mice, Microbiol. Res. 171 (8), 97, 2015.

60. NAIDU N.A. Vitamin $\mathrm{C}$ in human health and disease is still a mystery? An overview, Nutrition J. 4 (5), 2, 2003.

61. VIAUD SACCHERI F., MIGNOT G., YAMAZAKI T., DAILLÈRE R. The intestinal microbiota modulates the anticancer immune effects of cyclophosphamide, Science 22 (5), 971, 2013.

62. MAMEDE A.M., TAVARES S.D., ABRANTES A.M., TRINDADE J., MAIA J.M., BOTELHO M.F. The role of vitamins in cancer: a review, Nutrit. Cancer 63 (4), 479, 2011.

63. SMIRNOFF M. Ascorbic acid metabolisms and functions: a comparison of plants and mammals, Free Rad. Biol. Med. 2018, https://doi.org/10.1016/j.freeradbiomed.2018.03.033.

64. NEFIĆ H. The genotoxicity of vitamin $\mathrm{C}$ in vitro. Bosn. J. Bas. Medic. Scienc. 8 (4), 141, 2008.

65. FATTA-KASSINOS D., MERIC S., NIKOLAOU A. Pharmaceutical residues in environmental waters and wastewater: current state of knowledge and future research. Anal Bioanal Chem 399, 251, 2011. 
